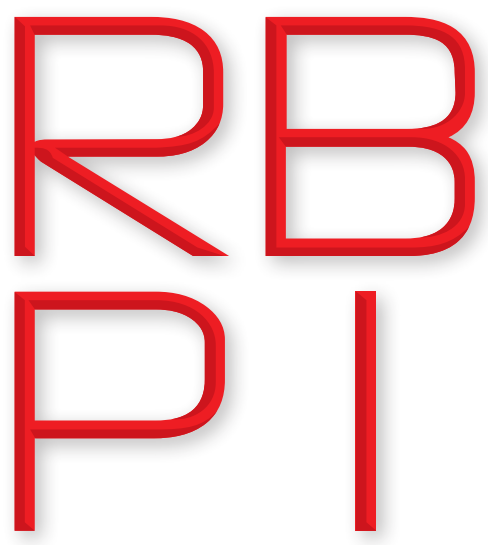

Revista Brasileira de Política Internacional ISSN 1983-3121

http://www.scielo.br/rbpi

\section{Andrew Hurrell}

Oxford University, Balliol College, Oxford, United Kingdom

(andrew.hurrell@balliol.ox.ac.uk).

\section{Copyright:}

- This is an open-access article distributed under the terms of a Creative Commons Attribution License, which permits unrestricted use, distribution, and reproduction in any medium, provided that the original author and source are credited.

- Este é um artigo publicado em acesso aberto e distribuído sob os termos da Licença de Atribuição Creative Commons, que permite uso irrestrito, distribuição e reprodução em qualquer meio, desde que o autor e a fonte originais sejam creditados.

\section{Towards the Global Study of International Relations}

DOI: http://dx.doi.org/10.1590/0034-7329201600208

\section{Abstract}

This article reviews recent critiques of the wester-centrism of mainstream International Relations. It argues that the overriding challenge is to try to move beyond critique and to develop a global study of international relations that insists on the importance of the systemic, of the global, but that also takes the critiques seriously and builds on them productively.

Keywords: Eurocentrism; International Relations Theory; Area Studies; Non-western IR; Global International Society.

Received: November 17, 2015

Accepted: February 1, 2016

\title{
Introduction
}

One might expect International Relations to be global by its nature; in terms of the substantive questions that it addresses; and as a result of the continued expansion of the subject especially in the developing and emerging world. And yet the apparent globalization of the discipline is not reflected in its dominant theories, concepts and approaches, which remain largely derived from European and U.S. history and practice, and heavily dominated by institutions and scholars in the West. As presented in the standard textbooks, the established traditions of thought, all of the major paradigmatic debates and all of the discussions of methodological innovation and advance focus on western traditions of thought and on models and ideas derived predominantly from western experience.

For some, of course, this is how it should be. Empirical social science is about universal or at least generalizable knowledge. Why not travel the world taking with you the most sophisticated tools and the latest available methods? In a similar manner western political theory has explored many different routes whereby rational agents might come to agree on ahistorical and universal 
norms, and a central goal has been to seek to achieve distance from historical situatedness and to avoid the snares of old-style historicism.

As this Special Issue illustrates, such a view has come under sustained scrutiny and critique. Scholars have demonstrated just how far mainstream International Relations has been all too little aware of the deeply western-centric character of its assumed historical narratives, its allegedly universal theoretical categories, and its political preoccupations. Much critical attention has been devoted to the claim that 'IR' must be understood from different perspectives, especially from below and from the standpoint of the subaltern and the marginalized. There has been a significant increase in work that is concerned precisely with IR and the non-western world and with the need to 'de-centre' and to 'provincialize' the study of 'International Relations'. On this account we can only understand the 'one world' if we see it from the perspective of 'many worlds'.

I shall review some of the most important elements of this critique in the first part of this article. The difficulty is that, all too often, conferences are held and the critiques are repeated but little seems to change. Indeed, the political introspection of western societies and the internally-driven academic agenda of western International Relations may well be getting worse. A dialogue of the deaf therefore ensues; and theoretical tribalism continues unabated. In these circumstances the overriding challenge is to try to move beyond critique and the explore how we might move towards the global study of international relations that insists on the importance of the systemic, of the global and of the 'one world'; but that also takes the critiques seriously and seeks to build on them productively. By 'we' I mean here the ever-growing range of IR scholarship across the world and the culturally pluralist and politically diverse community of IR scholars, working in many different countries and drawing on a range of disciplines. Contestation and challenge are fundamental to any intellectual endeavour; but so too is the need to find a productive basis and shared language around which to contest and to challenge.

If we want to continue to probe the western-centric character of writing on International Relations and to give a fuller account of regional and non-western paradigms and understandings, then we need to begin by asking why the already quite extensive list of critiques is not adequate. Acknowledging the value of much existing critical work, the second part of this article will therefore suggest various areas of weakness: the importance of looking beyond the world of IR theory and the power embodied in patterns of knowledge production; the need to re-think what critical scholarship involves within different contexts; the need to pay close attention to the way in which shifting patterns of power affect our view of who or what needs to be de-centered; and lastly, the enormous challenge of acknowledging the power of the global and the ways in which the dominant and institutionally embedded languages of international relations constrain what can be argued politically, and contain powerful explanatory and normative ideas that cannot be ignored. The final section looks at how the agenda might move forward, building on the unavoidable imperative to incorporate the power of the global whilst being sensitive to differently situated regional, historian and cultural contexts. 


\section{International Relations and Western Dominance}

There is now a large and flourishing body of writing that emphasizes the close links between western power and dominant approaches to the academic study of International Relations. One part of this work has re-examined both the history of modern international society and the historical development of the academic study of International Relations. Critical and post-colonial scholarship, for example, has opened up a very different historical account of the 'rise of the West' and has challenged both the easy dichotomy between the 'West' and the 'Non-West' and also the confident and complacent image of a global international society created via the universalization of essentially European institutions for the maintenance of order and the pursuit of justice. We now have a far more nuanced understanding of the ways in which western ideas about political and social order were always deeply and inextricably bound up in the international, the global and the non-western. Thus we can see, for example, the extent to which early modern western constructions of property and sovereignty were closely connected with empire and with the process of extra-European conquest and colonialism (Tuck 1999). And we can understand the close historical relationship between European cosmopolitan ideas and the spread of empire (Pagden 2000). Other contributions included the role of imperialism in the development of international law (Anghie 2005); and the role of race and racialized identities in western international relations (Vucetic 2011).

We can also see far more clearly just how closely western IR was almost wholly driven by the need to find answers to the colossal failures of western modernity that had, in the course of the first half of the $20^{\text {th }}$ century, produced unparalleled carnage and conflict. The mid- $20^{\text {th }}$ century realists sought to portray international relations in terms of the eternal recurrence of power politics based on the drive to dominate and an on innate human lust for power. But, whatever their theoretical claims, they were in fact seeking to respond to the crisis of liberal modernity; and their understandings of what constituted international relations can only be fully understood in this context.

In terms of the more contemporary study of the subject much critical attention has been devoted to the claim that 'IR' must be understood from different perspectives. We now have a sophisticated and still developing body of knowledge that insists that mainstream western IR is sorely inadequate for understanding the problems and the dynamics of the Global South. It is these authors and analysts - collected together by people like Arlene Tickner, Ole Weaver and Amitav Acharya, but drawing on many others working in different parts of the South. It is these writers who been most critical of the western-centric character of IR and who have stressed the elitist and exclusionary patterns of knowledge production in the western academy (Tickner and Weaver 2009; Acharya and Buzan 2010; Shilliam 2010). There has also been a significant increase in work that looks at the IR academia beyond the western core, and at the particular political, institutional and intellectual challenges that it faces. In many parts of the world the starting point for any discussion of this subject is the degree to which IR has 
developed overwhelmingly as an American social science at precisely the time when the United States was uniquely powerful. The US-centered nature of much of international relations and the evident link between IR theory and western or US practice constitute major subjects of debate and contestation. How might one best engage with US theory despite its normative blindspots and its particularist concerns? Here debates about theory, about the nature of explanation, and about normative evaluation often merge with the question of how to define the agenda of what matters, and how to present an identity or a vision that reflects local traditions, local values and local circumstances.

This body of work has made many very important arguments. A very incomplete list might include the following: that we must devote far more attention to IR as it is understood and experienced 'from below'; that we need to understand much more about the agency of the apparently 'powerless'; that common concepts such as 'security' have a very different meaning and content when seen from below; and that the 'international' itself is a malleable and unobvious category. In fragile states and penetrated systems, the division between the 'international' and the 'domestic' appears very differently compared to those living with a world whose dominant intellectual framing is that of the Weberian state. This kind of critical project has also sought to deconstruct the imagined geographies and taken-for-granted macro-categories that do so much (often unseen) analytical work - for example the categories of developed/underdeveloped or First World and Third World (Doty 1996); or the extent to which the labels of 'emerging powers' and the BRICS are themselves constructed by powerful actors in the core of the system.

Much of the most interesting work in this vein has sought to sought to theorize history and historicize theory. Let me give the example of recent institutionalist theory. A very great deal of recent mainstream IR has been concerned with institutions and with questions of governance. The starting point was an unquestioned assumption that globalization was the dominant global reality. Institutions are needed to deal with the ever more complex dilemmas of collective action that emerge in a globalized world. The complexity of the governance challenges meant that international law and international regimes would necessarily increase in number, scope and variety. For most institutionalists most cooperation problems take place within the context of an already institutionalized status quo. The question is therefore pre-eminently one of institutional choice. Of course, exit and the exercise of 'go-it-alone power' remain on the menu of choices. But even large states are constrained, both because of issue- and institution-specific interests and because of the power-cementing and power-legitimizing role of institutions. So the focus is on choice and agency. The dominant metaphor is one of a market for governance: the complexity of the market followed from the natural functional differentiation of modernity characterized by an ever increasing range of issue-specific bodies of rules or sites of cooperation, each often involving multiple actors, multiple levels, and multiple logics.

These background assumptions about the system as a whole may appear rather modest. But they are not. They imply a world in which distributional conflict is secondary to efficiency, in which institutions have internal logics of path-dependent development, and in which legitimate 
power depends on sets of values that have become institutionally embedded. So power conflicts and distribution are pushed into the background, whilst value conflict is subsumed within the pale language of preferences. The shared recognition of the problem to be solved, the shared sense of potential benefits from cooperation, the legitimacy of the players round the table, and the existence of a shared language for communication and contracting are all simply assumed. The historical preconditions for these assumptions are rarely investigated or at least are left on the margins of the analysis - the apparent stability of a western- and US-dominated geo-political order and the belief in long-run modernizing dynamics which will work against the sorts of ideological or cultural divergences that had all too often stood in the way of effective governance in the past. From this perspective western writing on governance and institutions all too easily slips into an analysis of how 'we' can 'order' and 'govern' globalization in a way that preserves western primacy and reflects 'our' own values and interests.

This leads to the critics to a very different view of what 'liberal' global governance looks like when seen from 'below' and from the 'outside'. Jean Cohen characterizes this sort of position as follows:

From this optic, the discourses and practices of humanitarian or democratic intervention, transformative occupations, targeted sanctions, terrorist blacklists and so forth (much of which was driven by the US since 1989) are mechanisms to foster the de-formalization of existing international law, so as to enable the very powerful (the US or the 'West') and/or those states aspiring to become twenty-first century great powers (Russia, China) to create self-serving global rules instead of being ways to limit power by law.... Global governance and global law serve to authorize new hierarchies and gradations of sovereignty, to legitimate depredations of political autonomy and self-determination in new ways which are disturbingly reminiscent of the heyday of nineteenth-century imperialism. (Cohen 2014, p. 126)

We can therefore see just how far recent western debates on global order were dominated by a dual liberal hegemony: a historicist hegemony that has too easily assumed that history is moving down a one-way street; and an analytical liberal hegemony that has tended to work with a narrow notion of agency; with too little room for the historical analysis of the structures within which supposedly ahistorical logics of rational choice and collective action play out;

\section{The Limits of Critique}

All this has been extremely important, but is it adequate for our present task? There are five reasons for believing that it is not.

In the first place, and especially within some branches of post-colonial IR writing, there has been an excessively Foucauldian concern with knowledge-production, and with the politics 
of representation and discourse. This view correctly stresses the extent to which non-mainstream and alternative understandings of identity, subjectivity and difference have been written out of the western IR script. It also highlights the degree to which the very categories used by academics clearly reflect and reinforce structures of productive and discursive power. And yet, this has often translated into a rather internalist concern with theory and with what might constitute 'non-western theory'. Whilst western dominance of knowledge-production in IR remains clearly important, it should not obscure the shifting patterns of power, hierarchy and inequality that are at work in the world.

Now one response is to say that, as far as IR theory is concerned, nothing is really changing. It is still a neo-imperialist field of enquiry and control over the intellectual means of knowledge production has hardly shifted. This is all that really matters. But it is a post-modern conceit to give so much weight to representations. At the minimum, we need to try to separate out-in a way that much post-colonial analysis of course rejects-the differences between power within the IR academy and changing patterns of power, distribution and stratification in the world.

In a related vein, the post-modern fascination with difference - especially in this context between the 'West' and the 'non-West' - can lead to an extreme stress on otherness that is extraordinarily unhelpful - analytically and normatively. The political and normative problems are highlighted by Rowan Williams:

By absolutizing the other, otherness becomes un-thinkable; the laborious process of evolving a practice in which my desire, my project, redefines or rethinks itself in symbiosis with others, a practice in which the presence of scarcity ceases to be simply the occasion of "war", is avoided. (Williams 1995, p. 5) ${ }^{1}$

Second, in going down the critical road, it is often rather easy to be trapped by accounts that stress the foreign policy ideas and foreign policy orientations of particular countries. The constructivist emphasis on norms and identity can often end up uncomfortably close to the official positions of governments and of writers and academics close to governments. For all their pretensions to critical distance, the discursive strands of critical theory and of some variants of constructivism can easily be trapped by the discourse that they are attempting to deconstruct. This is especially the case given that the target of much critical scholarship has been a rather one-dimensional view of the US or the West. And yet the uncovering and development of a 'Chinese school of IR' or a Brazilian or Indian 'perspective' on international relations can lead to a situation in which a perhaps justified political objective undercuts the academic need for rigor and for critical distance. Achieving academic distance is made harder because of increased politicization and polarization. We are witnessing a resurgence of nationalist agendas in many of the core states and regions of the world, and freedom of speech and the values of academic

1 I have stressed the underrated importance of both agency and moral accessibility in thinking on how inevitably centred particular conceptions of global justice might be negotiated. See On Global Order, chapter 12. 
freedom and academic integrity have come under increasing challenge. These challenges come from many sources: measures to address terrorism and radicalization; demands to redress past injustices; and calls for the reassertion of particular national, religious or cultural values and for the voices of those in academia or in the public sphere to be restricted or curtailed if they are not seen to be promoting or reflecting those values.

Uncovering the culturally specific character of particular ways of understanding the world undoubtedly encourages greater pluralism and reflexivity. But it can also lead to a cultural and regional inwardness that may work to reproduce the very ethnocentricities that are being challenged.

Third, because much critical and post-colonial writing has concentrated on the power of the West and the neo-liberal core, other important relationships and patterns of interaction have been side-lined. This is especially the case with what we would now call South-South relations. Historically, for example, Manjapra (2010) has highlighted the importance of such connections in the generation of southern cosmopolitan ideas, especially during the anti-colonial struggle. Indeed, re-reading the story of decolonization opens up much closer connections between nationalism, internationalism and cosmopolitanism, thereby putting into question the dominant western view that the Third World was always concerned with national sovereignty.

Looking beyond a North/South prism can also lead us to ask different questions about the political units that make up international relations. An important line of critique has been that the mythology of 'Westphalia' invoked an image of a world of sovereign and equal nation-states. In so doing it massively underplayed the fact that the dominant major powers, both within the classical European system and the Cold War world were empires, or imperial nation-states or hegemonic formations. As against this reality, the non-western world sought to use the mythology of Westphalia to its own advantage, adopting the language and practice of statehood and sovereign equality. And, following from this, the much of the debate about the IR of the developing world has been about the fate of the state in different parts of the world - 'failed states', 'limited statehood' and so on. Again this has been very important. And yet it is also important not to equate hierarchy and empire solely with western power. Current shifts in power against western dominance may well involve renewed centrality for political entities that are not straightforward 'nation-states': non-western political formations that have very deep-rooted hegemonic self-perceptions; states that see themselves as 'region-states'; and states that see themselves as 'civilizational states' or the bearers of particular religious values.

A fourth difficulty comes from the extent to which so much critical and post-colonial work often appears committed to a rather static view of power, hegemony and hierarchy. Post-colonial work, in particular, seems to build on an all-encompassing view of western power, US hegemony, and neo-liberal globalization. It also seems, implicitly at least, to accept the old categories of North and South and of Third World at a time when these spatial categories and taken-for-granted historical geographies are eroding and unravelling. One need not be committed to any particular set of claims about power diffusion or the degree to which power has in fact 
shifted away from the western core. However, the point is simply that something is changing. 'Global' is assuming a new character: not just increasing connectivity and integration, as for the theorists of globalization; nor just a global space in which the major powers play out their competition; but rather a greater drive and capacity from an increasing number of places to contest the terms and nature of what the global order both is and might be about.

If power is shifting, where exactly is it shifting to? One view is that power is simply shifting to major emerging states as part of the on-going dynamic of the rise and fall of Great Powers. This is the whole point of stories about 'Superpower China', 'India Rising' or 'Brazil's Moment'; and about the rise of the BRICS. We can debate exactly who these new actors are, how they have behaved in the past, and what they might want in the future. Yet the issues are familiar ones and have fundamentally to do with what 'they' will do with 'their' power - a limited number of important new actors acquiring substantial amounts of new power. An alternative view, however, is that we are witnessing a much more general diffusion of power, and especially disruptive power. These patterns of diffusion are linked to technological changes, to changes in the global economy and to new forms of social and political mobilization. Thus if rising China is one central part of contemporary global politics, the Arab Spring is another.

The idea of shifting power and the changing context cannot be reduced to indices of material power. The 'power structure' is changing partly because of shifting power in the narrow sense, but also because of changing notions of legitimacy. How can 15 per cent of the world claim to speak for the 'international community'?. It is also changing due to the centrality of emerging states and societies for shared problems, and because of the huge impact that social upheaval and political crises in these societies will have - whether feeding back negatively into inter-state relations, especially via nationalism; or in terms of preventing coordinated and effective international action on shared problems. Finally, the power structure is also changing because finding stable and renewed domestic bargains to social justice or stable capitalism cannot be done on a single-country basis. So the renewed centrality of major power politics does not depend simply on a 'who's up and who's down' calculus.

This leads to the final limitation, or perhaps better, the final challenge: how to explore the regional and the local without neglecting the continued, and perhaps increasing, power of the global. Why should this be such a problem? In part because of the centrality of global dynamics and logics: logics of traditional geopolitical competition and of new security threats; logics of global capitalism (both the power and fragility of globalized markets); and logics of social and technological change and the dramatically increased capacity for political mobilization and societal awareness. And in part, because, unlike many other areas of social science, there is only one global order. There is no outside, and both the older languages of international law and society and the newer languages of global governance provide the unavoidable languages within which global political life is both debated and practiced.

As we have seen, the natural move on the part of those who seek to critique dominant western understandings of global governance is to 'de-center' International Relations. However, 
given the power of the global, there are no longer (if there ever were) any non-western regional or cultural perspectives that can be gathered together in any straightforward or unproblematic manner. The sheer power of the global means that attempts to identify a 'Chinese' or an 'Indian' understanding of International Relations will always face severe methodological difficulties.

There are, broadly, two ways in which a global order might come into being. One is via the coming together on more or less equal terms of a series of regionally-based systems, whether made up of states, empires or other political groupings. The other is by the global dominance of what was an originally regional system. It is this model that stands behind the global order of the twentieth century with its expansion of an originally European international society on to a global scale. This happened partly through the globalizing force of capitalism and the immense transformative impact that it has on the regions and societies which were drawn into a deepening system of exchange and production relations; partly through the emergence of an often highly conflictual international political system which, as Mackinder (1904) argued, came to see the entire Earth as the single stage for promotion of the interests of the core powers of the system; ${ }^{2}$ and partly through the development of a global international society whose institutional forms (the nation-state, Great Powers, international law, spheres of influence) were globalized from their originally European context in the course of European expansion and the subsequent process of decolonization. Understandings of these global logics emerged in the course of the $19^{\text {th }}$ century and became central to the practice of western power in the $20^{\text {th }}$ century. And they remain enormously powerful today. They continue to structure how global order is understood and debated in the West. Western thought continues to be influenced by the legacies of Mill, Mackinder and Marx; and, in terms of its broader philosophical commitments, as Sanjay Seth (2002) suggests, by the work of Kant and of Hegel.

But if the global is so powerful, then why do we need to de-center at all? Take, for example, the foreign policies of emerging powers in the global South. To the mainstream IR theorist, much here seems all too familiar. In contrast to so much of the vacuous rhetoric of globalization, the foreign policies of the emerging world seem to involve a clear reassertion of many aspects of a 'return to Westphalia'. The state and state-based projects of national power and national assertion appear to be central to most of what is going on inside many emerging and regional powers. From this perspective it is simply erroneous to suggest that the state is not central to the IR of the Global South. Of course we need to understand variations in the kinds of state and to note that there are many varieties of state and nation-building which, even if they share an elective affinity with the European 'original', are distinctive and different. But seemingly universal processes of state-building and nation-building are taking place, and are closely connected to patterns of IR with which mainstream theory seems rather comfortable. Hence,

2 Mackinder stressed the closing of the frontier and the notion of the international system as 'a closed political space'. 'Every explosion of social forces, instead of being dissipated in a surrounding circuit of unknown space and barbarian chaos, will be sharply re-echoed from the far side of the globe, and weak elements in the political and economic organism of the world will be shattered in consequence' (1904, p. 422). 
we need to look to the established western toolkit of ideas about the power of global capitalism, or about the power-political behaviour of emerging powers and about the changing character of international legal order. Of course, if we take this view, we will need to pay particular attention to resistance and rejection, and also to the complexity of processes of socialization, diffusion and localization. However, from this perspective, none of this should distract us from the centrality of the global and the reality of how an originally western but now widespread set of understandings about the global have come to shape international relations in all parts of the emerging world.

Or again, when faced with, say, the previous Brazilian government's rhetoric about Southern solidarity or the need for new global norms, the realist will always be tempted to ask: so what's new? Rising powers have always sought to mobilize the dominant or aspirant norms of the system to their own advantage - think of Germany (with national self-determination) or Japan (with racial equality) in the inter-war period. Rising regional powers have always sought to find a legitimating regional discourse to engender 'followership' on the part of weaker states. To stress these trends does not commit one to a crude neo-realist account of the inevitability of major power conflict. The sorts of changes sketched above certainly bring back into focus the importance of power and contestation. But they also open up the possible role for more power-centered accounts of order and governance. This perspective is stressed both by classical realists but, especially, by international society writers who see Great Powers and Great Power concerts as fundamental to the ordering of international society. Within the contemporary system, one natural response to shifting power is to return to a far more Great-Power-centered order - both to avoid tensions and potential conflict amongst the existing and rising powers but also to achieve the consensus needed to tackle the new and complex global challenges. This can involve the reform of formal multilateral institutions - such as bringing new members on the UN Security Council - or the formation of new groupings. But the essential point is that the basic toolkit, which was once narrowly western, is now far more truly global.

The same might also be said for critical and normative ideas of the global. Martti Koskenniemi (2012) captures very nicely the tension between the messy and power-cementing role of international law on the one hand and the importance of the practice of law and of legal argument in expressing and debating collective projects on the other.

Statehood, self-determination, sovereignty, minority rights, secession, non-use of force are all part of the institutional vocabularies that make it possible to express the character of collective life as a 'project'. Included in that 'project' are our institutions and practices as platforms on which the point of that project is constantly imagined, debated, criticized and reformed, over and over again. ... International law invites everyone to participate in the imagining of humankind's collective telos, not despite its indeterminate character but precisely by virtue of its openness (Koskenniemi 2012). 


\section{The Way Forward}

So the question remains: how to understand a global order in which there are complex patterns of power diffusion and even more complex patterns of social, economic and political change, in which our inherited categories of analysis are eroding, and in which new hierarchies and inequalities are becoming established? We certainly need to pluralize, to relativize, and to historicize. And, for all the reasons given above, we need to recognize the continued power of Chakrabarty's (2000) claim that western analytical and theoretical categories remain indispensable but inadequate. We cannot escape from the disciplinary and theoretical western mainstream. But concepts and ideas never travel unproblematically. We would surely also want work that de-centers other regional or cultural perspectives and that problematizes unreflective 'non-western' theories. A major goal must be to avoid a narrowly 'critical' or 'Southern' view, and, instead, seeking to encourage differently situated scholars to theorize about their own experience, whether empirically or normatively; and whether this means connecting with western social science or mounting a challenge to it. Five more specific points can be made.

In the first place, we need to take the power of the global very seriously but at the same time to recognize that neither capitalist globalization (for the liberal and Marxist) nor global power competition (for the neo-realist) produces homogenization; and that each demands a deep understanding of how the global plays out in particular contexts. The global and the general are so important and so powerful that they must be placed centre stage in our analysis. The option of not confronting what is happening at the global level out of a deep suspicion of grand narratives and big historiographical stories is not sufficient. It is for this reason that the recurrent binary thinking that has underpinned so much liberal writing on International Relations and global order has been so unhelpful. Examples of this binary thinking can include setting a supposedly consolidated peaceful liberal core vs a periphery of failed states and ungoverned spaces; or seeing a group of responsible liberal democracies in clear opposition to a group of irresponsible nationalist and authoritarian states. Indeed, the need is to understand the relation between the outside and the inside and to track the processes by which western ideas of international order and capitalist modernity have been transposed and translated into different national and regional contexts and to the mutual constitution of ideas and understandings that resulted from that interaction.

In some cases, perhaps most plausibly China, on-going integration may well involve a questioning or re-casting of the fundamental social categories of western social thought - state, market, civil society. In other cases we need to be constantly alert to what Cardoso once labelled the 'originality of the copy' (Hurrell 2010). In many places, relations of space, time and belonging have shifted so that 'North' and 'South' co-exist simultaneously within the same geographical space (Harvey 2009). The mixed and hybrid character of the global order means that we need to be especially alert to the recombination of old and new not just at the level of global order but also at the level of the state and of state-society relations domestically. Here one might 
focus less on groups such as the BRICS, and more on the intellectual and policy 'bricolage' - to use Mary Douglas's term - that has been taking place within each of the emerging states and through which old and new ideas and policies are melded together in ways that are working against these states becoming simply absorbable within some expanded version of a liberal Greater West (Douglas 1986). Instead of continuing to work around a tradition/modernity dichotomy, the need is to re-focus attention on the multiple structural transformations that are taking place within modernity.

The importance of thinking in this way is reinforced by the degree to which the western historical teleologies underpinning so much western liberal writing on global order have frayed or eroded. Take the case of democratization. Western thinking had moved by the mid-1980s away from stressing the limits of democratic change in the developing and emerging world to stressing the breadth and depth of demands for more inclusive, responsive, and accountable systems of government, as well as the potential for productive democracy promotion. As the 1990s progressed, however, democratization theorists have had ever greater difficulty in understanding the succession of surprises and disappointments in terms of actual democratic outcomes, despite a generally favourable external and global environment. Many democracies, old as well as new, have failed to meet the demands and expectations for more responsive political systems. Interventionist democracy promotion has failed from Iraq to Libya to Afghanistan. And non-democracies have more confidently asserted policies of active resistance to preferred Western models. Whilst the social drive for accountability and responsiveness show little sign of abating, there appears to be neither any clear universal model nor an easily identifiable pathway to greater democratization, but rather a multiplicity of complex and cross-cutting trajectories. Democratization is therefore an increasingly uncertain foundation stone or modernizing narrative that can reinforce the sort of legitimating values (democracy, human rights, and the rule of law) that many have adopted as central to their preferred model of global order.

Few are likely to dispute the proposition that contemporary global order is being challenged and shaped by the revival of geopolitical rivalries. Many might also accept that some of the most convincing accounts of new patterns of realist-inspired power competition rely on a far more social view of the system, and a much more constructivist account of the identities of states and actors. But the crucial point is surely that stressed by Rogers Smith (2004) notably that as students of politics, we must be especially attentive to the politics of identity: explicitly politicizing identity claims; de-naturalizing identity claims, historicizing identity claims. His own work is all about the politics of multiple and contested stories of 'peoplehood' and deeply contested traditions. As scholars of global order, we constantly need to be suspicious of culturalist accounts, not because culture does not matter but because it is with the politics of culture that we need to be concerned. So, for example, when we are presented with accounts of Brazil's supposedly pacific identity we need to see this as a historically contingent set of identity claims and to ask exactly how they emerged and precisely whose power and interest they reflect. 
It is also surely the case that, as Marx predicted, global capitalism transforms the societies with which it comes into contact. Yet, at the same time, the cultural and historical traditions of those societies shape the manner in which 'capitalism' takes on a specific social and political meaning and manifestation. As Wolfgang Streeck states:

While recent analyses of institutional change had made progress in classifying certain formal properties of the processes found to be at work in the real world of contemporary capitalism in general terms, they were unable to speak to the underlying causes of such processes. They also remained unconnected to the growing literature that had become dissatisfied with universalistic representations of 'the economy' as nature, or as a black box, returning for remedy to the concept of capitalism as a historically specific socio-economic order. (Streeck 2010 , p. 6) ${ }^{3}$

A second important goal is to develop concepts and conceptual frameworks that emerge from particular regions and contexts but that then have more general application and relevance. Of course understanding difference is crucial, both the apparently radically different and the apparently similar. Even if the language is shared, the real meaning may be very different. Policy-makers may talk a language of powers and the balance of power, but the precise meaning and implications of these concepts may well differ considerably from their western ideal-typical meaning. Rather than concentrate on the 'radically different', it is the 'nearly the same' that is often of greater importance in the analysis of non-western international relations.

A really crucial point is the one stressed by Iain Johnston (2012). For Johnston, area studies is not about the exotic and the esoteric; it is part of how we can do good social science. Hence his important work arguing that mainstream analysis of East Asia and of absolutely mainstream IR concerns (the rise of China, major power rivalries etc.) is weakened by a lack of understanding of the region. The may involve mistaken coding and data collection, omitted variable bias, and, most important, conceptual impoverishment. Yes, we are interested in hierarchy and hegemony. So why would we ignore or downplay the understandings and rich conceptualizations of hierarchy in Asia? They should be explored not just because we want to understand Asia but precisely in order to generate better general categories of analysis - for understanding global order generally. The regional needs to be played back into the global, the insights of the many worlds back into our understanding of the one world. Hence we certainly want to understand what is distinctive and different - why Putin's world is so radically different from those who write about the EU as a normative power. But it is also, and very crucially, about how differently-situated ideas and practices may come to have more general relevance for current and future policy challenges.

The question, then, is what the non-western world can do for Political Science more generally (Tsai 2013). In some cases, this may well have to do with concept development. In others it might be more about opening up the range of comparative research. Western social science remains a prisoner of particular patterns of comparative work that grew out of the way in

3 I owe this reference to Julian Gruin. 
which disciplines developed and regional and area studies were formed. Again from intellectual history we know that western academic disciplines and the structure of area studies grew out of $19^{\text {th }}$ century Europe and reflected national and imperial political interests. So 'who compares what with what and why?' needs to be part of the de-centered study of international relations. Equally, whilst comparative research reigns methodologically supreme, we spend much less time thinking about connectivity (how are the regional and the global connected?) and about the specific methodological problems involved in comparing across large regions.

Conceptual questioning and conceptual reconstructing may also take us back to history. Recent work has usefully stressed the crucial role of the $19^{\text {th }}$ century in creating the modern world of global international relations (Buzan and Lawson 2013). Yet even more than stressed by Buzan and Lawson, we need to understand better the historical construction of notions of time and history, and of space and globality, without which modern western understandings of global order make very little sense. On time we need to explore the way in which the very structuring conception of history in the later $18^{\text {th }}$ and early $19^{\text {th }}$ century rewrote the past, placed limits on the possibilities of political and historical imagination in the present, and produced new intellectual ways of world-making that were predicated on the intellectual history of the rise of the nation-state. On space, it is important to develop further work on the creation of regional studies, on the construction of the global and of globality; on the myths of regions and continents; and on the ways in which the global is not just the site of intensifying global connections but is also the site of the mutual constitution of both the global and the local. And there also remain important silences. If the racial and civilizational underpinnings of ideas of global order are well known, the religious remain far less explored - although they are very obvious to many who approach the history of western thinking from the outside. Charles Taylor (2007) for example, brings out the extent to which the taken-for-granted quality of what he calls the 'immanent order' is only explicable against a very particular process of western secularization. And the neglect of Christianity in the historical development of Wilsonianism is one of the more striking gaps in the more recent history of international political thought. (For an exception see Babik 2103).

A third important issue concerns the study of the normative and the global study of political ideas. The normative analysis of International Relations is perhaps the most western-centric of all. Cosmopolitan liberal understandings of global justice have been framed in terms of achieving justice for individuals; it was about what 'we' in the rich world owed distant strangers. Here, of course, we find the enormous growth of work on distributive justice, especially on the part of those who have sought to deploy Rawlsian approaches at the global level. At the same time, it is important to note that most of this work saw the post-Cold War dominance of the US and the West not as a problem but as an opportunity to be exploited. If this involved interventionism, paternalism, even renewed empire on the part of the rich and powerful then so be it-so long as social justice was being promoted. Very little of this work made reference to the self-understandings of the 'objects' of justice in the non-western world. 
One part of the challenge here is political: actually listening and noting the views and values that are expressed and argued in different parts of the non-western world. Even at the level of government policy, the problem often seems to be more one of 'Do the dominant listen?' rather than 'Can the subaltern speak?' Another part of the problem is methodological. The study of western political theory has advanced hugely in methodological terms: contextualism, conceptual history, reception theory, theories of ideology etc. However, the study of global political theory remains in its infancy (Goto-Jones 2010; Godrej 2011; Rao 2010; Jenco 2007).

Another element involves looking beyond understanding and engagement. Much of the critical engagement with non-western normative political theory has been driven by the goal of interpretation, of provincializing the categories of western theory, of promoting dialogue, and of seeking greater reflexivity. But, as with explanatory theory, the goal must be to avoid ghettoizing the contributions of the 'non-west'. It is important to escape from unhelpful macro units of analysis ('Islamic' ideas, 'Chinese' values), and to explore how ideas that emerge from different historical, developmental and cultural contexts can have more general, even global relevance and application.

A final area for exploration concerns contending global narratives. We suggested earlier in this chapter that an enormous amount of work within western thinking on global order and governance has depended on a set of mostly $19^{\text {th }}$ century narratives about history and time, space and modernity. Particularly in their liberal incarnation it is these that often produce the greatest incredulity when viewed from outside. The critique comes in different forms but the core point is clear:

Thus complex social formations - up to and including whole world orders - can be described as liberal, while simultaneous practices demonstrably integral to those formations, such as racism or colonial and imperial violence, are asserted not to be liberal... liberal order secures its status as essentially peaceful by denying a set of articulations and relations - especially across the liberal/non-liberal divide - that have repeatedly and routinely been linked with it. (Laffey and Nadarajah 2012)

It is perhaps around the study of different and alternative narratives of the global and their contestation that the re-articulation of the study of global order might begin.

\section{Conclusion}

In this article I have tried to show how the debate between 'one world/many worlds' within International Relations came about, and what some of the most elements in that debate have been. I have tried to suggest that the overriding challenge is to explore how we can move beyond critique and seek collectively to develop, to debate and to contest the global study of international relations. 
In many, perhaps most, countries of the world those studying International Relations face a paradox: politics is everywhere becoming more inward-looking; publics and electorates are reacting to the pressures and dynamics of an unequal and restless global order; and established political and party systems are in disarray. Except in the form of critique it is all too often very hard even to discuss questions of global order. 'International Relations' seems a very long way away. In addition, the subject often finds itself on the defensive, both within academia and in the policy world, for example when compared to the authoritative claims made by Economics.

And yet the claims of academic International Relations, including with its traditional focus on inter-state and major power relations, are more important than ever. In the first place, 'International Relations' are a far more central element of globalization than is often recognised. Globalization is usually seen in contradistinction to the state and as something that poses a fundamental challenge to the state. And yet the globalization of the state was arguably the most important aspect of globalization. In part this follows from the deep connections between the drivers of globalization in particular periods and patterns of inter-national and inter-imperial politics. In part, and more fundamentally, the most ignored - or taken-for-granted - aspect of globalization has been the globalization of the nation-state. For the first time in human history there is a single global political system with a set of legal and political institutions, diplomatic practices, and accompanying ideologies that developed in Europe and then the wider western world and which, in the traditional parlance, 'expanded' to form a global international society.

Second, the dynamics of this globally expanded society of states are of tremendous significance at a time when we have witnessed a return of geopolitics. the overt geopolitical conflicts visible in the South China Sea, in Ukraine and the Crimea, and in North East Asia; the extent to which geopolitical rivalry can spill-over into, for example, resources competition or cyber-wars, or even the negotiation of economic and trade deals (as in the negotiations across the Atlantic and Pacific). It is of course possible to see these developments simply as international relations returning once more to its 'Westphalian norm'. But it is more accurate and more helpful to face up to the complex, hybrid and contested character of international society - a society that faces a range of classical Westphalian challenges (especially to do with power transition and the rise of new powers); but one that faces these challenges in a context marked by strong post-Westphalian characteristics (in terms of the material conditions of globalization, the changed character of legitimacy, and the provincializing of Westphalia). We live in a far more diverse world, with more participants, and with a far greater range of voices and views. Many of these participants come from parts of the world that played no part in the creation of the order in which they are now playing a far more prominent role.

And third, the fact that parallel political crises are happening in so many different places suggests strongly that global and systemic factors must be at work. We cannot understand the crisis in Brazil or the immense challenges to the EU solely by looking at individual cases. Something more strongly global is at work. And it is International Relations that has a strong claim to be 'the' academic field where there is the richest tradition of analysing how the global 
evolved historically, how different systemic and global factors and forces interact (especially global capitalism and the distribution of inter-state power), and how the political and normative constructions of global order can best be understood and debated. It is in this sense that Fred Halliday suggested that International Relations was the capstone discipline of the social sciences. And yet, as this article has sought to argue, we can only fulfil this potential and this promise if we seek to bring together the one world and the many worlds - analytically, historically, politically and normatively.

\section{References}

Acharya, A. and Buzan B. eds., 2010. Non-Western International Relations Theory: Perspectives on and Beyond Asia. London: Routledge.

Anghie, A., 2005. Imperialism, Sovereignty and the Making of International Law. Cambridge, UK: Cambridge University Press.

Babik, M. 2013. Statecraft and Salvation. Wilsonian Liberal Internationalism as Secularized Eschatology. Baylor: Balyor University Press.

Buzan B. and Lawson G. 2013. The Global Transformation. The $19^{\text {th }}$ Century and the Making of Modern International Relations. Cambridge UK: Cambridge University Press.

Chakrabarty, D., 2000. Provincializing Europe: Postcolonial Thought and Historical Difference. Princeton, NJ: Princeton University Press.

Cohen, J.L., 2014. Reply to Scheuerman's review of 'Globalization and Sovereignty'. Global Constitutionalism, 3(1), pp. 119-141.

Doty, R.L., 1996. Imperial Encounters: The Politics of Representation in North-South Relations. Minneapolis, MN: University of Minnesota Press.

Douglas, M., 1986. How Institutions Think. Syracuse, NY: Syracuse University Press.

Godrej, F., 2011. Cosmopolitan Political Thought: Method, Practice, Discipline. New York: Oxford University Press.

Goto-Jones, C., 2010. Comparative Political Thought: Beyond the Non-Western. In: D. Bell ed., 2010. Ethics and World Politics. Oxford, UK: Oxford University Press, pp. 219-238.

Harvey, D., 2009. Cosmopolitanism and the Geographies of Freedom. New York: Columbia University Press.

Hurrell, A., 2010. Cardoso and the World. In: H. Martins and M.A. D'Incao eds., 2010. Democracia, crise e reforma. Estudos sobre a era Fernando Henrique Cardoso. São Paulo: Editora Paz e Terra. pp. 473-499.

Hurell, A., 2007. On Global Order. Power, Values and the Constitution of International Society. Oxford, UK: Oxford University Press.

Jenco, L.K. 2007. "What does Heaven Ever Say?” A Methods-Centered Approach to CrossCultural Engagement. American Political Science Review, 101(4), pp. 741-755. 
Johnston, A.I., 2012. What (if anything) does East Asia tell us about International Relations Theory? Annual Review of Political Science, 15(2012), pp. 53-78.

Koskenniemi, M., 2012. Law, Teleology and International Relations: An Essay in CounterDisciplinarity. International Relations, 26(1), pp. 3-34.

Laffey, M. and Nadarajah, S., 2012. The Hybridity of the Liberal Peace: States, Diaporas and Insecurity. Security Dialogue, 43(5), pp. 403-420.

Mackinder, H.J., 1904. The Geographical Pivot of History. The Geographical Journal, 23(4), pp. $421-437$.

Manjapra, K., 2010. Introduction. In: S. Bose and K. Manjapra eds., 2010. Cosmpolitan Thought Zones: South Asia and the Global Circulation of Ideas. Basingstoke, UK: Palgrave Macmillan, pp. $1-19$.

Pagden, A., 2000. Stoicism, Cosmopolitanism, and the Legacy of European Imperialism. Constellations: An International Journal of Critical and Democratic Theory, 7(1), pp. 3-22.

Rao, R., 2010. Third World Protest: Between Home and the World. Oxford, UK: Oxford University Press.

Seth, S., 2002. Back to the Future? Third World Quarterly, 23(3), pp. 565-575.

Shilliam, R. ed., 2010. International Relations and Non-Western Though. Imperialism, Colonialism and Investigations of Global Modernity. London: Routledge.

Smith, R.M., 2004. Identities, Interests and the Future of Political Science. Perspectives on Politics, 2(2), pp. 301-312.

Streeck, W., 2010. Taking Capitalism Seriously: Towards an Institutionalist Approach to Contemporary Political Economy. Max Planck Institute for the Study of Societies Discussion Paper 10/15. Cologne: Max Planck Institute for the Study of Societies.

Taylor, C., 2007. A Secular Age. Cambridge, MA: Harvard University Press.

Tickner, A. and Waever, O. eds., 2009. International Relations Scholarship Around the World. London: Routledge.

Tsai, K., 2013. China's Political Economy and Political Science. Perspectives on Politics, 11(3), pp. 860-871.

Tuck, R., 1999. The Rights of War and Peace: Political Thought and the International Order from Grotuis to Kant. Oxford, UK: Oxford University Press.

Vucetic, S., 2011. The Anglosphere. A Genealogy of Racialized Identity in International Relations. Palo Alto, CA: Stanford University Press.

Williams, R., 1995. Between Politics and Metaphysics, Reflections in the Wake of Gillian Rose. Modern Theology, 11(1), pp. 3-22. 